\title{
Wettability and surface free energy on \\ heat-treated Pinus sp. and Erisma sp. woods
}

\author{
Grau de umectação e energia livre de superfície em \\ madeiras Pinus sp. e Erisma sp. tratadas termicamente
}

\author{
Analine Crespo Ziglio', Sabrina Nicoleti Carvalho Santos ${ }^{2}$, \\ Nadine Mendes ${ }^{3}$ e Débora Gonçalves ${ }^{4}$
}

\begin{abstract}
Resumo
Este estudo tem como objetivo investigar a molhabilidade (grau de umectação), polaridade de superfície e perda de massa de duas madeiras de florestas plantadas, Pinus sp. (softwood) e Erisma sp. (hardwood) após tratamento térmico. As amostras de madeira foram tratadas termicamente a $100{ }^{\circ} \mathrm{C}, 140{ }^{\circ} \mathrm{C}$ e 180 ${ }^{\circ} \mathrm{C}$ e comparadas às amostras em temperatura ambiente, $25^{\circ} \mathrm{C}$. A fim de obter o ângulo de contato, foram depositados diferentes solventes nas superfícies das madeiras tratadas com calor. A partir dessas medidas, foram calculados os valores de energia livre de superfície, em termos dos componentes polares e dispersivos, pelo método Owens-Wendt-Rabel-Kaelble. As madeiras se mostraram hidrofóbicas em temperaturas abaixo de $180^{\circ} \mathrm{C}$, isto é, com relativamente altos ângulos de molhabilidade e baixa polaridade superficial, mas sem alterações visuais e dimensionais mais drásticas. O impacto do tratamento térmico nas propriedades de superfície de Pinus sp. e Erisma sp. foi também verificado por meio da inoculação de um fungo (Pycnoporus sanguineus). As madeiras Erisma sp. tratadas termicamente, quando comparadas com Pinus sp., apresentaram melhores propriedades, tais como estabilidade de massa, polaridade superficial e grau de umectação.
\end{abstract}

Palavras-chave: energia livre de superfície, ângulo de contato, degradação por fungo, umectação.

\begin{abstract}
This study aims to investigate wettability, surface polarity, and mass loss in two reforestation woods, Pinus $s p$. (softwood) and Erisma sp (hardwood), after heat treatment. The wood samples were heated to 100 ${ }^{\circ} \mathrm{C}, 140{ }^{\circ} \mathrm{C}$ and $180^{\circ} \mathrm{C}$, meanwhile a control group was kept at a fixed temperature of $25^{\circ} \mathrm{C}$. Different test liquids were employed in order to obtain the contact angles (wetting angles) formed on the heat-treated sample surfaces. From such measurements, the values of surface free energy, in terms of its polar and dispersive components, were calculated by the Owens-Wendt-Rabel-Kaelble approach. Temperatures far below $180^{\circ} \mathrm{C}$ proved to be high enough to yield hydrophobic samples, i.e., with relatively high wetting angles and low surface polarity, but without drastic visual and dimensional changes. The impact of heat treatment on the surface properties of Pinus sp. and Erisma sp. was also verified by fungal inoculation (Pycnoporus sanguineus). Compared to Pinus sp., heat-treated Erisma sp. showed improved properties, such as mass stability, surface polarity and wettability.
\end{abstract}

Keywords: surface free energy, contact angles, decay fungi, wettability.

\section{INTRODUCTION}

There are many methods of heat treating wood aiming at improving durability and mechanical resistance (OLIVEIRA et al., 2010; SRINIVAS; PANDEY, 2012). However, relatively high temperatures $\left(225-325^{\circ} \mathrm{C}\right)$ may produce irreversible deterioration of wood, causing drastic color changes, loosening of fibers, dimensional changes, and surface cracks (ESTEVES; PEREIRA, 2008; KUTNAR et al., 2013; OLIVEIRA et al., 2010). The most common protocols for the heat treatment of wood describe

\footnotetext{
${ }^{1}$ Doutora em Ciência e Engenharia de Materiais. USP - Universidade de São Paulo / IFSC - Instituto de Física de São Carlos. Avenida Trabalhador São Carlense, 400 - 13566-590 - São Carlos, SP, Brasil. E-mail: analinecz@yahoo.com.br

${ }^{2}$ Doutoranda em Ciência e Engenharia de Materiais. USP - Universidade de São Paulo / IFSC - Instituto de Física de São Carlos. Avenida Trabalhador São Carlense, 400 - 13566-590 - São Carlos, SP, Brasil. E-mail: ncs.sabrina@gmail.com

3Graduada em Engenharia Biotecnológica. UNESP - Universidade Estadual "Júlio de Mesquita Filho". Campus Assis - Av. Dom Antonio, 2100 - 19806-900 - Assis, SP, Brasil. E-mail: nadinemendes@gmail.com

${ }^{4}$ Professora Associada. USP - Universidade de São Paulo / IFSC - Instituto de Física de São Carlos. Avenida Trabalhador São Carlense, 400 - 13566-590 - São Carlos, SP, Brasil. E-mail: deborag0405@gmail.com
}

Sci. For., Piracicaba, v. 45, n. 113, p. 161-167, mar. 2017 DOI: dx.doi.org/10.18671/scifor.v45n113.16 
temperatures ranging from $160{ }^{\circ} \mathrm{C}$ to $240{ }^{\circ} \mathrm{C}$, but biologically durable timbers can be obtained with reduced capability for moisture absorption. Heat-treated woods become surface protected even at temperatures far below $200{ }^{\circ} \mathrm{C}$, which are high enough to produce hydrophobic, water-repellent surfaces by the removal of volatile extractives (KOCAEFE et al., 2015; OLIVEIRA et al., 2010).

Studies on surface properties are still far from being exhaustive as far as woods with different compositions are concerned (softwoods and hardwoods). Our group has studied Araucaria angustifolia and Pinus elliottii before and after thermal treatment from $20^{\circ} \mathrm{C}$ to $200{ }^{\circ} \mathrm{C}$ (OLIVEIRA et al., 2010; SOARES et al., 2011). Here, Pinus sp. (softwood) and Erisma sp. (hardwood) were studied up to reach a lower temperature, $180^{\circ} \mathrm{C}$. Such species are chemically different, widely available, and applied in the construction, paper and pulp industries. Calculation of surface free energy for wood samples from results of contact angles enables ones to evaluate how surface polarity varies with the heat treatment. Surface free energy and its components are critical parameters aiming at revealing differences in wood/liquid interface characteristics (MANTANIS; YOUNG, 1997). The presence of volatile extractives and products formed by oxidative pyrolysis of wood are able to produce hydrophobic surfaces and reduce surface polarity, which should be properly measured. Inasmuch as thermal modification in woods fundamentally yields different surface features, the susceptibility of Pinus sp. and Erisma sp. was also studied with regards to fungal decay (Pycnoporus sanguineus).

\section{MATERIAL AND METHODS}

Pinus sp. (Pinus Taeda) and Erisma sp. (Qualea albiflora Warm.) from planted forests were donated by LaMEM, EESC/USP, São Carlos-SP (Brazil), and obtained from the outer, sapwood parts of trees. The woods were cut into $(5.0 \times 3.0 \times 0.5) \mathrm{cm}^{3}$ pieces, and were dried in a conditioning chamber at $103 \pm 2{ }^{\circ} \mathrm{C}$ for $6 \mathrm{~h}$ (Erisma sp.) and $9 \mathrm{~h}$ (Pinus sp.) from a green state (anhydrous mass) to a point of equilibrium moisture content of $12 \%$, which is recommended for wood-based products (CALIL JUNIOR et al., 2003). A set of samples was treated in an oven from room temperature to operating temperatures of $100{ }^{\circ} \mathrm{C}, 140{ }^{\circ} \mathrm{C}$, and $180{ }^{\circ} \mathrm{C}$ for $10 \mathrm{~h}$ at $3{ }^{\circ} \mathrm{C} \mathrm{min}{ }^{-1}$. This heating protocol was chosen based on our previous results (OLIVEIRA et al., 2010; SOARES et al., 2011). All wood samples were weighed and stored under vacuum at $25{ }^{\circ} \mathrm{C}$. A set of samples was left untreated (control samples).

Contact angles $(\theta)$ were measured for untreated $\left(25^{\circ} \mathrm{C}\right)$ and heat-treated samples $\left(100{ }^{\circ} \mathrm{C}, 140\right.$ ${ }^{\circ} \mathrm{C}$, and $180^{\circ} \mathrm{C}$ ) by the sessile drop method (OLIVEIRA et al., 2010; SOARES et al., 2011). Drops of $8.0 \mu \mathrm{L}$ of four test liquids: water, ethylene glycol, formamide, and diiodomethane were deposited at different positions on the wood surfaces. The droplet images were analyzed using the arithmetic means of three contact points for the drop profiles by software Cam2008.

Surface free energy $(\gamma)$ was calculated by considering the solid (S)-liquid(L) interactions in equilibrium with the vapor phase. Total surface energy $\left(\gamma^{t}\right)$ was obtained as a sum of non-polar, dispersive (d), and polar (p) contributions (LAMPROU et al., 2010), and the values of $\theta$ were related to $\gamma$ via the Owens-Wendt-Rabel-Kaeble (OWRK) approach (QIN et al., 2015; QIN et al., 2014; VÁZQUEZ et al., 2011), Equation (1):

$$
\left(\frac{\gamma_{L}(\cos \theta+1)}{2 \sqrt{\gamma_{L}^{d}}}\right)=\sqrt{\gamma_{S}^{d}}+\left(\frac{\sqrt{\gamma_{L}^{p}}}{\sqrt{\gamma_{L}^{d}}}\right) \sqrt{\gamma_{S}^{p}}
$$

where $\gamma_{\mathrm{L}}{ }^{\mathrm{p}}$ and $\gamma_{\mathrm{L}}{ }^{\mathrm{d}}$ are the polar and dispersive components of $\gamma^{\mathrm{t}}$, and can be calculated from the values of $\theta$ in water (W), ethylene glycol (E), formamide (F), and diiodomethane (D) using a commercial spread sheet software program. Since there are two unknowns, $\gamma_{L}{ }^{p}$ and $\gamma_{L}{ }^{d}$, in Equation (1), at least two liquids are necessary to be used in the calculation; one with a predominant polar component and the other, with a predominant dispersive component. The component $\gamma_{\mathrm{L}}{ }^{\mathrm{p}}$ has a major contribution in water, while it is zero in diiodomethane; $\gamma_{\mathrm{L}}{ }^{\mathrm{d}}$ predominates for formamide and ethylene glycol (QIN et al., 2015). Surface polarity was calculated by taking the $\gamma_{\mathrm{L}}^{\mathrm{p}} / \gamma^{\mathrm{t}}$ ratio such as proposed for wood species (MANTANIS; YOUNG, 1997). 
For accelerated decay tests, a white-rot fungus, Pycnoporus sanguineus, donated by Universidade Federal de Pernambuco (Brazil), was used for inoculation (class: Basiodiomycetes, species: P. sanguineus). The culture medium was a mixture of Sabouraud-dextrose agar dissolved in $400 \mathrm{~mL}$ of hot water, which was autoclaved (Phoenix Luferco, AVplus) at $121^{\circ} \mathrm{C}$ for $15 \mathrm{~min}$, and deposited onto sterile Petri dishes in a laminar flow hood to prevent contamination (ZIGLIO; GONÇALVES, 2014). The fungus was inoculated by means of a swab onto the wood surfaces, which were subsequently placed into Petri dishes with nutrient agar at room temperature for 16 weeks. After this period of time, the samples were autoclaved for sterilization at $121^{\circ} \mathrm{C}$ for $20 \mathrm{~min}$, cleaned with a brush, and stored in a desiccator until reaching a stable value of mass. The values of mass loss ( $\mathrm{m}$ ) were obtained for the samples before and after the fungal decay. Such experimental conditions were chosen based on our previous results (ZIGLIO; GONÇALVES, 2014).

\section{RESULTS AND DISCUSSION}

Wood is rich in a large variety of colored compounds, which allows one to visibly distinguish different species. The process of thermal degradation of wood produces changes in color due to dark-brown quinones formed after oxidation of phenolic compounds (CARVALHO et al., 2014; MOURA; BRITO, 2011). Pinus sp. and Erisma sp. became darker from yellow to brown and light brown to dark brown, respectively, under treatment from $25^{\circ} \mathrm{C}$ to $180^{\circ} \mathrm{C}$ (Figure 1), which are not drastic color changes for these temperature variations.

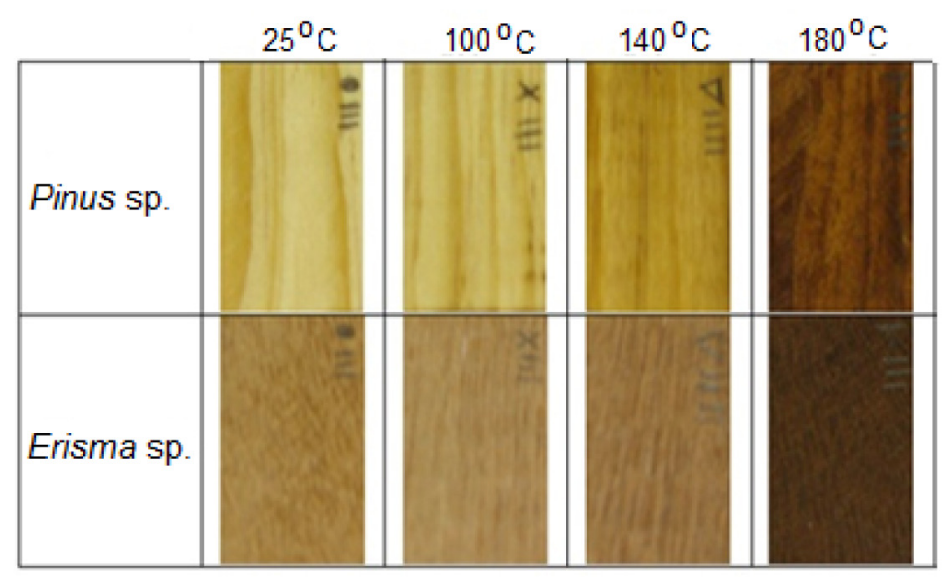

Figura 1. Cores de Pinus sp. e Erisma sp. quando tratadas termicamente em diferentes temperaturas. Figure 1. Colors of Pinus sp. and Erisma sp. when heat treated at different temperatures.

From Figure 1, it can be assumed that Pinus sp. and Erisma sp. are not dark enough to indicate significant effects of pyrolysis on their surface properties. However, even without considerable color changes, they suffered deterioration for some extent at relatively low temperatures so far as results of wettability and surface polarity have indicated.

The contact angles $(\theta)$ were obtained for Pinus sp. and Erisma sp. at a wood/liquid interface by using different testing liquids: water (W), formamide (F), ethylene glycol (E), and diiodomethane (D) (Figure 2).

The values of $\theta$ in Figure 2 are characteristically different for Pinus sp. and Erisma sp., in particular when testing with water (W). Erisma sp. shows the highest values of $\theta$ at $180{ }^{\circ} \mathrm{C}$, thus evidencing a hydrophobic character. Values of $\theta$ close to zero, on the other hand, implicate on complete wettability, such as obtained for Pinus sp. at lower temperatures. Besides, the values of $\theta$ were typically different in probes such as diiodomethane (nonpolar solvent), water and formamide (polar solvents).

Figure 3 shows the changes in surface free energy for untreated (control group) and heat-treated Pinus sp. and Erisma sp., and which were calculated from the values of $\theta$ (Equation 1). Surface polarity was also obtained as the ratio of the polar component of the surface free energy to the total surface free energy (dark-brown quinones $\gamma^{\mathrm{p}} / \gamma^{\mathrm{t}}$ ). 


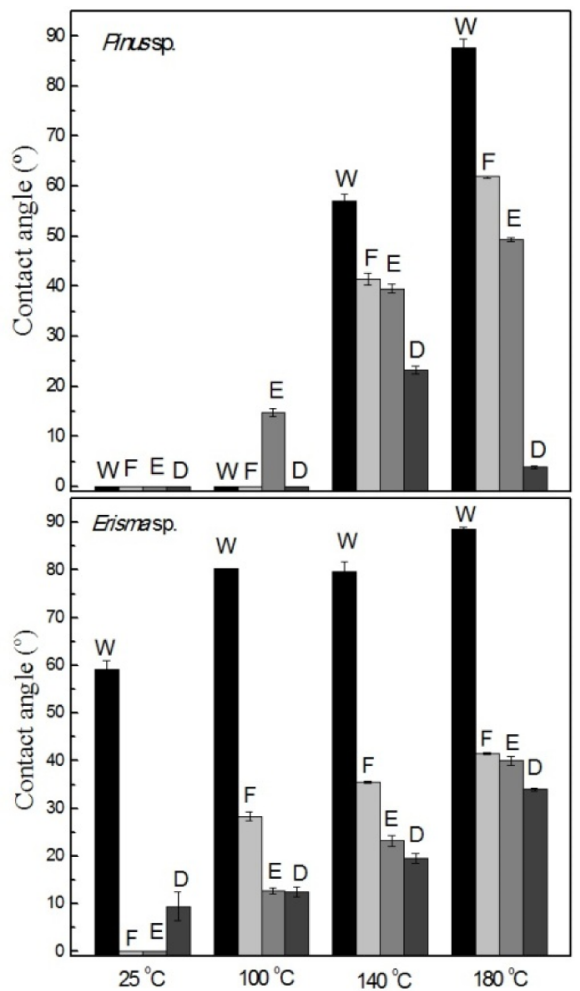

Figura 2. Variação do ângulo de contato em função da temperatura para Pinus sp. e Erisma sp. medidos com diferentes tipos de solventes (água, etilenoglicol, formamida e diiodometano).

Figure 2. Variation of contact angle versus temperature for Pinus sp. and Erisma sp measured by using different liquid probes (water, ethylene glycol, formamide, and diiodomethane).

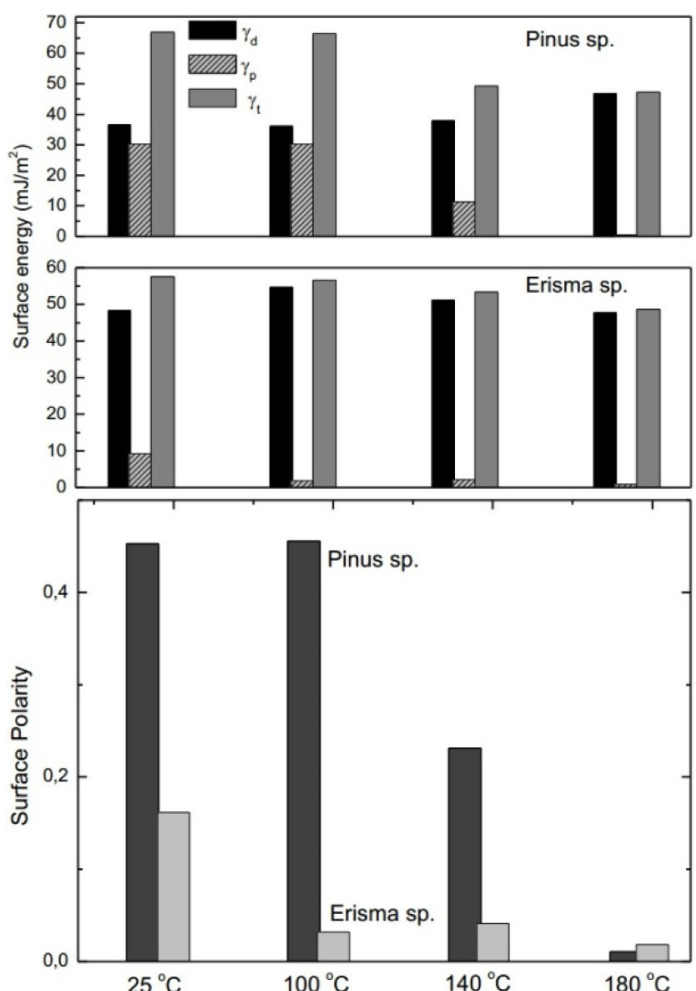

Figura 3. Energia livre de superfície e polaridade de superfície de Pinus sp. e Erisma sp. obtidos a partir das medidas de ângulo de contato.

Figure 3. Surface free energy and surface polarity of Pinus sp. and Erisma sp. as evaluated from the measurements of contact angles.

In addition to describing a wood surface as hydrophilic or hydrophobic, data in Figure 3 are even more conclusive. By comparing the values of total surface free energy $\left(\gamma^{t}\right)$, for Pinus sp. e.g., it can be verified they are practically the same for untreated samples and after being treated at $100{ }^{\circ} \mathrm{C}$. In this case, since the values of $\theta$ used in the calculations of $\gamma$ are close to zero, they gave similar contribu- 
tions for both dispersive $\left(\gamma^{\mathrm{d}}\right)$ and polar $\left(\gamma^{\mathrm{p}}\right)$ components. However, for the samples heat-treated at $180{ }^{\circ} \mathrm{C}$, the polar component $\left(\gamma^{\mathrm{p}}\right)$ decreases in detriment to the dispersive component $\left(\gamma^{\mathrm{d}}\right)$, producing values of surface polarity (p) close to zero. The values of $\gamma^{t}$ decrease about $30 \%$ from untreated to heat-treated samples at $180^{\circ} \mathrm{C}$. Such decrease in surface polarity (p) can be explained by effects of thermal expulsion of water from inner channels of wood, and also, from decomposition of lignin, which can make the wood more hydrophobic.

By comparing Erisma sp. and Pinus sp., the values of $\gamma$ are markedly different (Figure 3); for Erisma sp. treated at $180^{\circ} \mathrm{C}$, dispersive component $\left(\gamma^{\mathrm{d}}\right)$ contributes significantly to the value of $\gamma$. Such effect can be attributed to a process of thermal degradation of extractives and hemicelluloses, since polar components move away from inner to outer layers of wood. As a consequence, heat-treated woods are most likely related to higher contact angles and low surface polarities. The results obtained here are in agreement from previous data of wettability of heat-treated Jack Pine woods by different liquid probes (HUANG et al., 2012). In this work, it was assumed that structural changes in lignin and cellulose reduce absorption of liquids after heating, especially water [16]. In general, since the amount of free hydroxyl and acetyl groups in wood decreases during heating, this precludes the formation of a dense cross-linked network and more hydrophobic surfaces. Besides, thermal softening of lignin can also be related to water-repellent wood surfaces since its glass transition temperature usually occurs at about $90{ }^{\circ} \mathrm{C}$ (GUNNELLS et al., 1994; HAKKOU et al., 2005). Such effects justify small values in surface polarity for both untreated and heat-treated Erisma sp. as compared with Pinus sp. (Figure 3).

In order to evaluate the resistance of heat-treated Pinus sp. and Erisma sp. to fungal decay (Pycnoporus sanguineus), measurements of $\theta$ were also made. However, values of $\theta$ with higher levels of uncertainty were obtained due to the presence of cracks or fissures in heat treated wood; they ranged from $67.1^{\circ} \pm 26.7^{\circ}$ (Pinus sp.) to $88.9^{\circ} \pm 25.2^{\circ}$ (Erisma sp.) in water. Although imprecise, these results have indicated that the samples change their surface characteristics from hydrophilic to hydrophobic after fungal decay. For Erisma sp., this result is even more evident, since the values of $\theta$ are closer to $90^{\circ}$, indicating that fungal decay involves predominantly consumption of polar components of wood. In this case, heat treatment reduces hygroscopicity, by decreasing chemical interactions with water, and, as a consequence, affects the performance of wood-decaying fungi (HOMAN et al., 2000). The ability of fungi to partly decay a variety of wood components depends on the action of ligninolytic enzymes, and white-rot fungi, such as Pycnoporus sanguineus, known for secreting enzymes and depolymerizing lignin (MEYSAMI; BAHERI, 2003), which is a structural biopolymer responsible for protecting cellulose. A wood surface can be considered to be predominantly polar (hydrophilic) if it contains accessible -OH groups in the cell walls, and hydrophilic, when it contains high amounts of highly polar cellulose, or hemicelluloses, as a compared to less polar lignin.

The mass loss obtained for the heat-treated samples, before and after exposure to Pycnoporus sanguineus (16 weeks), can be observed in Figure 4.

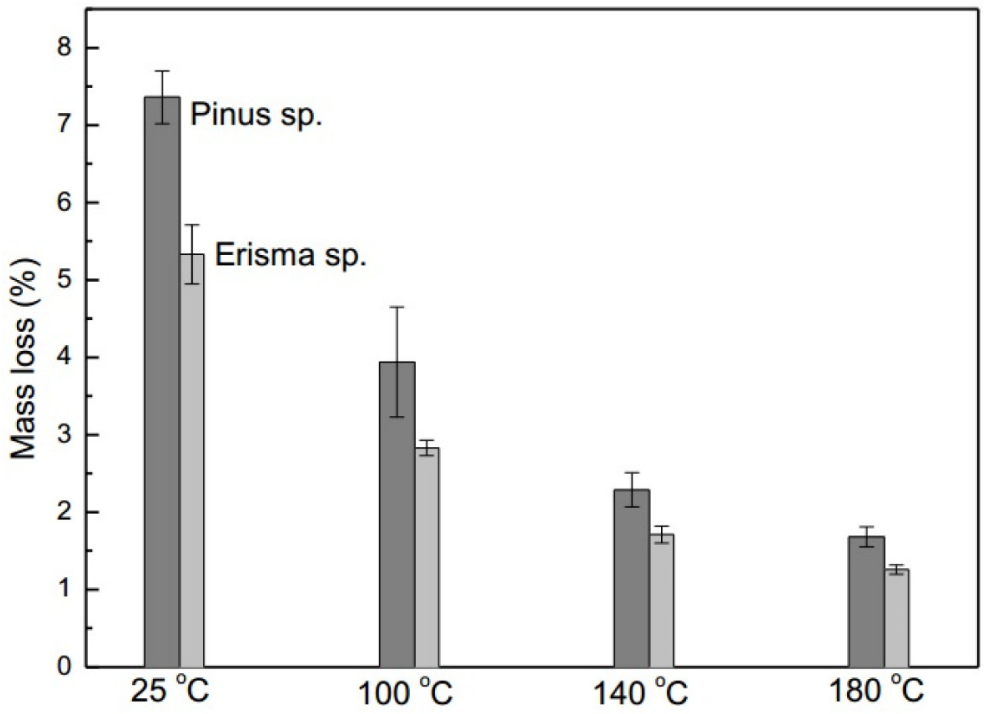

Figura 4. Perda de massa para Pinus sp. e Erisma sp. degradadas após tratamento térmico em diferentes temperaturas. Figure 4. Mass loss for decayed Pinus sp. and Erisma sp. after heat treatment at different temperatures. 
The mass loss decreased for the heat-treated samples, but both wood specimens have shown high resistance to white-rot fungal decay as compared with those untreated samples. Therefore, Erisma sp. is the most resistant wood to fungal decay, i.e., repellent to water; Pinus sp. is the most polar and more susceptible wood to deterioration in humid conditions. The methodology proposed here for obtaining the values of surface free energy and surface polarity is straightforward and non-invasive and can be applied to many heat-treated wood species.

\section{CONCLUSIONS}

Surface free energy and surface polarity were compared for two wood species; Pinus sp. and Erisma sp., and they were related to changes on wettability after treatment from $25^{\circ} \mathrm{C}$ to $180{ }^{\circ} \mathrm{C}$. Appropriate thermal treatments of woods make it easier to understand how surface modifications are induced by heating. This is a prerequisite for obtaining high quality woods with accurate properties, and which are necessary and in high demand in the market. Therefore, it is necessary to adapt analytical methods of characterization to control their surface quality and avoid expensive and time-consuming procedures. Here, it was verified that the thermal treatment used was able to change the hydrophilic nature of Pinus sp. and Erisma sp., which become rather hydrophobic, and with a non-polar character. These results show that temperatures higher than $180^{\circ} \mathrm{C}$, generally used for most common heat treatment of woods, are not necessary to modify their surface nature from hydrophilic to hydrophobic one. In this case, it takes place at lower temperatures without causing significant color and dimensional changes.

\section{ACKNOWLEDGEMENTS}

The authors would like to thank the financial agencies FAPESP (proc. 2012/13003-5) (Brazil), CAPES (Brazil), and Lemann Institute for Brazilian Studies, University of Illinois at Urbana-Champaign (USA).

\section{REFERENCES}

CALIL JUNIOR, C.; LAHR, F. A. R.; DIAS, A. A. Dimensionamento de elementos estruturais de madeira. São Carlos: Manole, 2003.

CARVALHO, A. G.; ZANUNCIO, A. J. V.; VITAL, B. R.; CARNEIRO, A. C. O.; SILVA, C. M. S. Colorimetric and chemical changes in pre hydrolyzed strand board particles of Pine and Eucalyptus. Bioresources, v. 9, n. 4 , p. $8,2014$.

ESTEVES, B.; PEREIRA, H. Wood modification by heat treatment: A review. BioResources, v. 4, n. 1, p. 370$404,2008$.

GUNNELLS, D. W.; GARDNER, D. J.; WOLCOTT, M. P. Temperature dependence of wood surface energy. Wood and Fiber Science, Madison, v. 26, n. 4, p. 447-455, 1994.

HAKKOU, M.; PÉTRISSANS, M.; EL BAKALI, I.; GÉRARDIN, P.; ZOULALIAN, A. Wettability changes and mass loss during heat treatment of wood. Holzforschung, Berlin, v. 59, n. 1, p. 35-37, 2005.

HOMAN, W.; TJEERDSMA, B.; BECKERS, E.; JORISSEN, A. Structural and other properties of modified wood. WORLD CONFERENCE ON TIMBER ENGINEERING. 2000, British Columbia. Anais... British Columbia, 2000

HUANG, X.; KOCAEFE, D.; BOLUK, Y.; KOCAEFE, Y.; PICHETTE, A. Effect of surface preparation on the wettability of heat-treated jack pine wood surface by different liquids. European Journal of Wood and Wood Products, v. 70, n. 5, p. 711-717, 2012. 
KOCAEFE, D.; HUANG, X.; KOCAEFE, Y. Dimensional stabilization of wood. Current Forestry Reports, v. 1, p. 11, 2015.

KUTNAR, A.; KRICEJ, B.; PAVLIC, M.; PETRIC, M. Influence of treatment temperature on wettability of Norway spruce thermally modified in vacuum. Journal of adhesion science and technology, v. 27, n. 9, p. 963-972, 2013.

LAMPROU, D. A.; SMITH, J. R.; NEVELL, T. G.; BARBU, E.; STONE, C.; WILLIS, C. R.; TSIBOUKLIS, J. A comparative study of surface energy data from atomic force microscopy and from contact angle goniometry. Applied Surface Science, v. 256, n. 16, p. 5082-5087, 2010.

MANTANIS, G. I.; YOUNG, R. A. Wetting of wood. Wood science and Technology, New York, v. 31, n. 5, p. 339-353, 1997.

MEYSAMI, P.; BAHERI, H. Pre-screening of fungi and bulking agents for contaminated soil bioremediation. Advances in Environmental Research, v. 7, n. 4, p. 881-887, 2003.

MOURA, L. F.; BRITO, J. O. Effect of thermal rectification on colorimetric properties of Eucalyptus grandis and Pinus caribaea var. hondurensis woods. Scientia Forestalis, Piracicaba, v. 39, n. 89, p. 69 - 76, 2011.

OLIVEIRA, R. M.; BRISOLARI, A.; SALES, A.; GONÇALVES, D. Wettability, shrinkage and color changes of Araucaria Angustifolia after heating treatment. Materials Research, São Carlos, v. 13, n. 3, p. 351-354, 2010.

QIN, Z.; CHEN, H.; GAO, Q.; ZHANG, S.; Li, J. Wettability of sanded and aged fast-growing poplar wood surfaces: I. Surface Free Energy. BioResources, v. 10, n. 1, p. 1008-1023, 2015.

QIN, Z. Y.; GAO, Q.; ZHANG, S. F.; LI, J. Z. Surface free energy and dynamic wettability of differently machined poplar woods. Bioresources, v. 9, n. 2, p. 3088-3103, 2014.

SOARES, A. C.; OLIVEIRA, R. M.; BRISOLARI, A.; SALES, A.; GONÇALVES, D. Wetting of Araucaria angustifolia and Pinus elliottii samples after thermal treatment and aging. Scientia Forestalis, Piracicaba, v. 39, n. 92, p. 447-456, 2011.

SRINIVAS, K.; PANDEY, K. Effect of heat treatment on color changes, dimensional stability, and mechanical properties of Wood. Journal of Wood Chemistry \& Technology, Philadelphia, v. 32, n. 4, p. 304-316, 2012.

VÁZQUEZ, G.; GALIÑANES, C. F.; FREIRE, M. S.; ANTORRENA, G.; GONZÁLEZ-ALVAREZ, J. Estudio del mojado y caracterización superficial por microscopía de barrido laser confocal de chapas de madera obtenidas por desenrollo. Maderas. Ciencia y tecnología, Concepcion, v. 13, n. 2, p. 183-192, 2011.

ZIGLIO, A. C.; GONÇALVES, D. On the use of capsaicin as a natural preservative against fungal attack on Pinus sp. and Hymenaea sp. woods. Materials Research, São Carlos, v. 17, p. 271-274, 2014.

Recebido em 08/03/2016

Aceito para publicação em 05/10/2016

Sci. For., Piracicaba, v. 45, n. 113, p. 161-167, mar. 2017 DOI: dx.doi.org/10.18671/scifor.v45n113.16 